\title{
1,2,3-Benzotiadiazin-1,1-dioxid származékok előállítása és átrendeződési reakciói ${ }^{+}$
}

\author{
GYÜJTŐ Imre, ${ }^{\mathrm{a}, \mathrm{b},{ }^{*}}$ PORCS-MAKKAY Márta, ${ }^{a}$ SIMIG Gyula, ${ }^{\mathrm{a}}$ NYULÁSZI Lászlób és VOLK Balázs ${ }^{{ }^{*}}$ \\ ${ }^{a}$ Egis Gyógyszergyár Zrt., Hatóanyagfejlesztési igazgatóság, Keresztúri út 30-38., 1106 Budapest, Magyarország \\ ${ }^{b}$ Budapesti Müszaki és Gazdaságtudományi Egyetem, Vegyészmérnöki és Biomérnöki Kar, Szervetlen és Analitikai Kémia \\ Tanszék, Szent Gellért tér 4., 1111 Budapest, Magyarország
}

\section{Bevezetés}

Az Egis Gyógyszergyár kutatói originális gyógyszerkutatási tevékenységük során azt célt tüzték ki maguk elé, hogy központi idegrendszerre ható 2H-1,2,3-benzotiadiazin-1,1dioxid (BTD) vegyületeket fejlesszenek (1. ábra). Egyfelől szerették volna tanulmányozni a BTD vegyületek farmakológiai hatását, ugyanis a BTD család analogonja a $2 H$-ftalazinon és a $2 H$-1,2,4-benzotiadiazin-1,1-dioxid vázaknak, amelyek gyógyszerhatóanyagokban is fellelhetők (pl. olaparib, talazoparib, ill. klorotiazid, hidroklorotiazid). Másrészt ezt a strukturális elemet farmakológiai szempontból előnyös részszerkezetekhez kívánták kapcsolni, hogy szabadalmi szempontból független új vegyületeket hozzanak létre.<smiles>O=c1[nH]ncc2ccccc12</smiles><smiles>[R]C1=NNS(=O)(=O)c2ccccc21</smiles>

$2 H$-1,2,3-benzotiadiazin-1,1-dioxid (BTD)

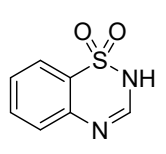

$2 H-1,2,4$-benzotiadiazin-1,1-dioxid
1. ábra. A BTD-ok fejlesztésének farmakológiai motivációja.
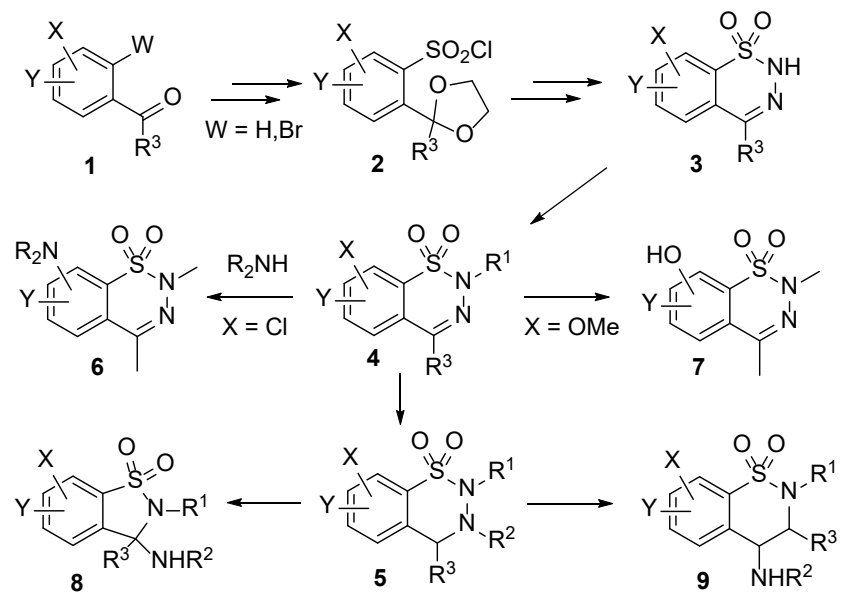

2. ábra. A kutatómunka célkitűzése.
Az Egis kutatói számos érdekességet fedeztek fel a BTD kémiában, amelyeknek részletes vizsgálatára nem került sor. Így a PhD értekezés célja az volt, hogy az elóállított BTD vegyületek körét szélesítsük, bemutassuk a továbbfejlesztett szintézisstratégiákat, és módszeresen körbejárjuk a felismert újdonságokat. Benzaldehid-acetálokból $\left(\mathbf{1}, \mathrm{R}^{3}=\mathrm{H}\right)$, valamint acetofenon- $\left(\mathbf{1}, \mathrm{R}^{3}=\right.$ alkil $)$ és benzofenon-ketálokból $\left(1, \mathrm{R}^{3}=\right.$ aril) több lépésben, a megfelelö szulfonsav-kloridokon (2) keresztül alakítottuk ki a BTD származékokat (3, 2. ábra). Ezután egyfelől $N(2)$-alkilezési $\left(\mathbf{3} \rightarrow \mathbf{4}, \mathrm{R}^{1}=\right.$ alkil), redukciót követő $N(3)$-acilezési $\left(\mathbf{4} \rightarrow \mathbf{5}, \mathrm{R}^{2}=\right.$ acil $)$, valamint aminokkal történő nukleofil szubsztitúciós $(\mathbf{4} \rightarrow \mathbf{6})$ és $O$-demetileződési $(4 \rightarrow 7)$ reakciókat hajtottunk végre. A másik feltérképezendő területet pedig a BTD-ok átrendeződési reakciói képezték $(\mathbf{5} \rightarrow \mathbf{8}$ és $\mathbf{5} \rightarrow \mathbf{9})$.

\section{Irodalmi háttér}

\subsection{A BTD váz kialakítása és reakciói}

A BTD váz (10) kialakítására néhány megközelítés ismert volt az irodalomból (3. ábra). Wright oaminobenzofenonokból (11) képzett diazóniumsókat $o$-aroilbenzolszulfonsav-kloridokká (12) alakított, amelyeket hidrazinnal reagáltatott. ${ }^{1}$ King 2-formilbenzolszulfonát nátriumsóját (13) használta kiindulási anyagként. ${ }^{2}$ Kacem szintézisstratégiája $N^{1}$-arilszulfonil-hidrazonátok (14) LDA/TMEDA rendszerben történő orto-lítiálásán alapult. ${ }^{3}$

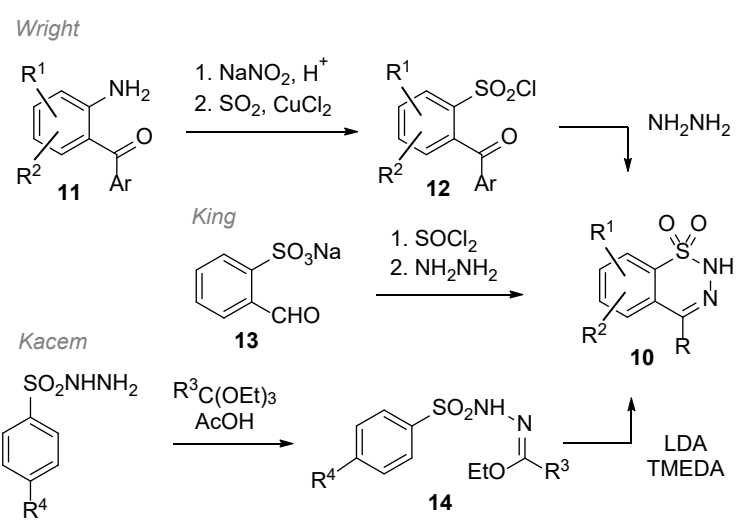

3. ábra. BTD-ok irodalmi szintézisei.

\footnotetext{
+ Gyüjtő Imre azonos címü PhD értekezéséhez kapcsolódó tézisfüzet alapján készült.

* Tel.: +36 1803 5874; e-mail: gyujtoimre@gmail.com, volk.balazs@egis.hu.
} 
Az Egis kutatói olyan reakcióutat kívántak kidolgozni, amely könnyen hozzáférhető kiindulási anyagokat felhasználva, az aromás gyürün különféle szubsztituenseket tartalmazó BTD-okat eredményez. Így esett a választás aceto- és benzofenonokra $(\mathbf{1 5}, \mathbf{4}$. ábra). A karbonilcsoportot etilén-glikollal maszkírozták, esetenként mikrohullámú (MW) körülmények között (4. ábra, fent). ${ }^{4}$ Az eljárás kulcslépése a dioxolanil vegyületek $(16,17)$ orto-lítiálása, és a kapott aril-lítium vegyületek kén-dioxiddal történő reagáltatása, amelyet szulfuril-kloriddal történő oxidatív klórozás követett, így jutva a megfelelő szulfonsavklorid-ketálokhoz $(\mathbf{1 8}, 19)$. Benzofenon-ketálok esetében ezt számos szubsztrátumon végrehajtották. ${ }^{5} \quad$ Acetofenon-ketáloknál elsődlegesen szén-dioxidot használtak elektrofilként a regi-

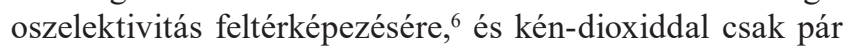
példát közöltek, ${ }^{7}$ azonban szabadalmi bejelentéseikben már számos példán bemutatták a gyürüzárási, alkilezési és $\mathrm{C}=\mathrm{N}$ redukciós eljárásaikat. ${ }^{89}$ A 4-es helyzetben szubsztituálatlan (4-H) BTD-ok (20) esetében a benzaldehidekböl (21) kiindulva hasonló módon kapott 2-klórszulfonil-acetálokból (22) a gyürüzárást két úton is végrehajtották (4. ábra, középen): hidrazinnal vagy acethidraziddal a védőcsoportok eltávolítását követően. ${ }^{10}$ A 4-H BTD-ok (20) alkilezése során $N(2)$-alkil- (23) és mezoionos $N(3)$-alkilszármazékok (24) keletkeztek (4. ábra, lent). ${ }^{11} \mathrm{~A} \mathrm{C}=\mathrm{N}$ kettős kötés redukcióját végrehajtották $\mathrm{NaBH}_{4} / \mathrm{TFA}$, illetve $\mathrm{PtO}_{2} / \mathrm{H}_{2}$ rendszerben $(\mathbf{2 0} \rightarrow \mathbf{2 5}, \mathbf{2 3} \rightarrow \mathbf{2 6}, \mathbf{2 4} \rightarrow \mathbf{2 7})$, valamint reduktív alkilezés során paraformaldehiddel metilcsoportot vezettek be 3,4-dihidroszármazékok 3-as helyzetébe $(\mathbf{2 5} \rightarrow \mathbf{2 7})$. Az $N(3)$-alkilszármazékok (27) $N(2)$-helyzetben végzett alkilezésével a megfelelő dialkilszármazékokat $(\mathbf{2 8})$ nyerték. ${ }^{12}$

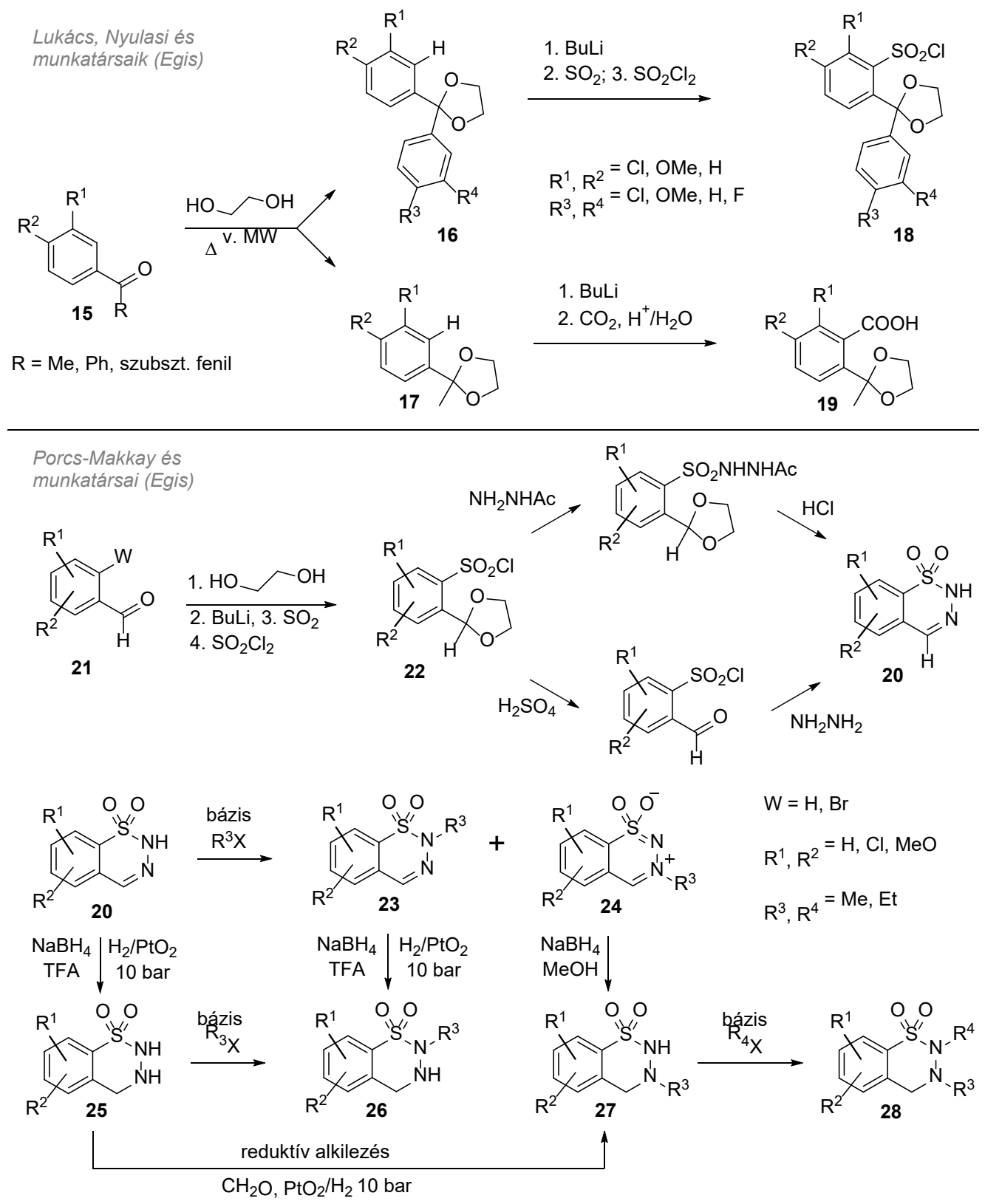

4. ábra. Az Egis eljárása ketálok orto-funkcionalizálására (fent), valamint a 4-H BTD-ok szintézisére (középen), alkilezésére és redukciójára (lent). 


\subsection{Stevens- és Wittig-átrendeződések}

A Stevens-átrendeződés során kvaterner ammóniumvegyületek $\alpha$-deprotonálódását követően kialakul egy ilid, majd tipikusan biradikális mechanizmussal [1,2]-vándorlás történik (5. ábra). ${ }^{13}$ Bázis hatására a hidrazóniumvegyületek hasonló módon $a z a$-[1,2]-Stevens-átrendeződésen mehetnek keresztül. ${ }^{14}$

[1,2]-Stevens

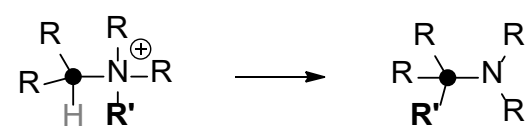

aza-[1,2]-Stevens<smiles>[R]N([R])C([R])([R])N([R])[R]</smiles>

[1,2]-Wittig<smiles>[R]O[C]([R])O[R]</smiles>

aza-[1,2]-Wittig<smiles>[R][R](=[R])N([R])[R]</smiles>

diaza-[1,2]-Wittig

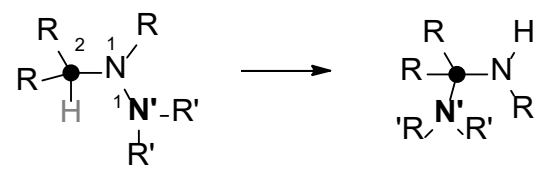

diaza-[1,3]-Wittig

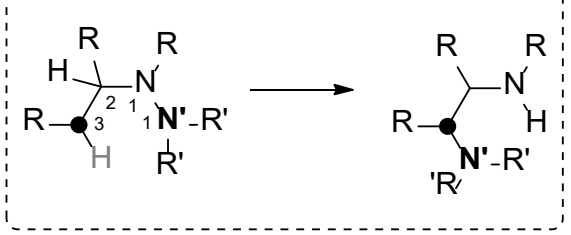

diaza-[1,4]-Wittig
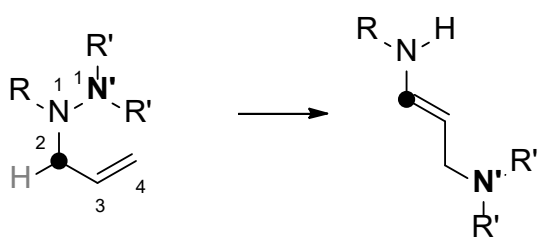

5. ábra. Stevens- és Wittig-átrendeződések, valamint $a z a$-analogonjaik.
Az [1,2]-Wittig-átrendeződésben az $\alpha$-helyzetű deprotonálódást követően hasad a $\mathrm{C}-\mathrm{O}$ kötés, és [1,2]-átrendeződés történik. ${ }^{15}$ A Wittig-átrendeződés $a z a$-analogonjai alapvetően abban különböznek a Stevens-átrendeződéstől, hogy nincs bennük kvaterner nitrogénatom. Az $a z a$-[1,2]-Wittig-átrendeződés során a $\mathrm{C}-\mathrm{N}$ kötés hasad. Ezen az analógián alapulva az N-N kötés hasadásával járó átalakulásokat diaza-[1,2]-Wittig-átrendeződésnek nevezhetjük (pl. $N$-fluorenilurazolok gyürübővülése $t$-BuOK hatására). ${ }^{16} \mathrm{~A}$ diaza-[1,4]-Wittig-átrendeződés szintén ismert, ${ }^{17}$ de a dia$z a$-[1,3]-Wittig-átrendeződés eddig hiányzó láncszem volt az átalakulások sorából.

\section{Eredmények}

\subsection{A 4-aril-BTD-ok előállítása és reakciói ${ }^{18}$}

A 4-aril-BTD-okat (29) a megfelelő o-klórszulfonil-ketálok (18) hidrazinnal vagy acethidraziddal történő gyürüzárásával állítottuk elő (6. ábra). Farmakológiai szempontból kedvezőnek ígérkezett a 2-alkil- (30), a 3,4-dihidro- (31) és a 2-alkil-3,4-dihidroszármazékokkal (32) foglalkozni. $\mathrm{NaH}$ vagy $t$-BuOK bázisok és alkil-jodidok alkalmazásával előállítottuk $30 N(2)$-metil-, etil- és butilszármazékot. Megállapítottuk, hogy 4-aril-BTD-ok esetén az N(2)alkilezés jó regioszelektivitással megy végbe, szemben a 4-es helyzetben szubsztituálatlan BTD-oknál korábban tapasztaltakkal, amikor is az $N(2)$ - és az $N(3)$-alkilezett termékek közel azonos mennyiségben keletkeztek. A 29 és 30 vegyületek $\mathrm{C}=\mathrm{N}$ kettőskötésének redukcióját $\mathrm{PtO}_{2}$ katalizátor jelenlétében, hidrogénatmoszférában, illetve egy esetben $\mathrm{NaBH}_{4}$-del TFA jelenlétében is elvégeztük, így 31 és 32 3,4-dihidroszármazékokhoz jutottunk.

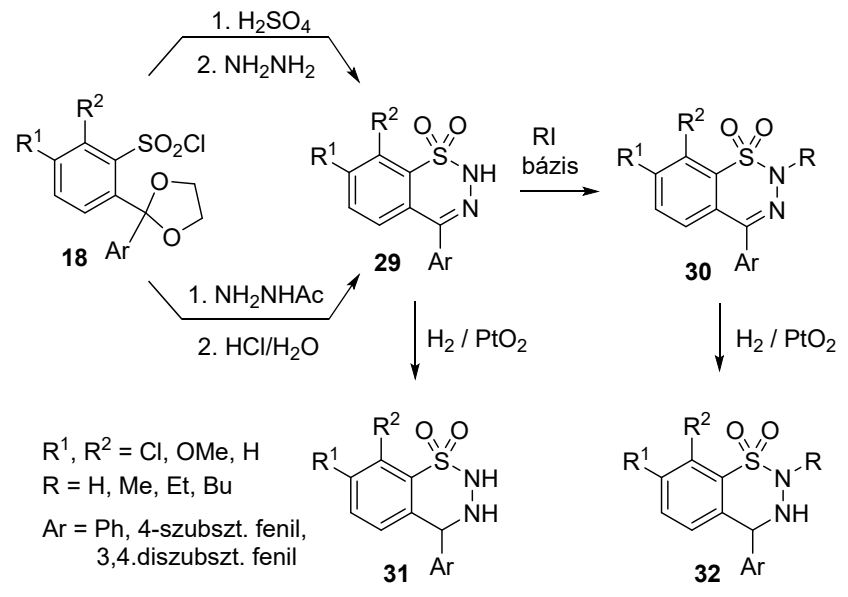

6. ábra. A 4-aril-BTD gyürü kialakítása, alkilezése és redukciója.

\subsection{A 4-metil-BTD-ok előállítása, alkilezése és redukciója ${ }^{19}$}

Részletesen kidolgoztuk a 4-metil-BTD-származékok (33) acetofenonokból (34) kiinduló szintézisét is (7. ábra). A karbonilcsoportot 1,3-dioxolánként védtük, etilén-glikollal MW körülmények között, vagy trietil-ortoformiát 
jelenlétében reagáltatva. A következő lépésben butil-lítiummal orto-lítiálást hajtottunk végre. Amennyiben az orto-lítiálás nem működött, a megfelelö 2-bróm-ketálokat $(\mathrm{W}=\mathrm{Br})$ lítiáltuk. Az aril-lítiumot kén-dioxiddal reagáltatva lítium-szulfinátot kaptunk, amelyet szulfuril-kloriddal oxidatív klórozásnak vetettünk alá, így szulfonsavklorid-ketálokhoz jutottunk. Végül a védőcsoportot savas körülmények között távolítottuk el, és a gyürüzárást hidrazinnal vagy acethidraziddal hajtottuk végre. Ezt követően $t$-BuOK bázissal és alkil-halogenidekkel metil-, etil- vagy benzilcsoportot vittünk be a 2-es helyzetbe $(\mathbf{3 3} \rightarrow \mathbf{3 5})$. Az $N(2)$-helyzetben szubsztituálatlan $(\mathbf{3 3} \rightarrow \mathbf{3 6})$ vagy 2 -alkil-BTD-vegyületek $(\mathbf{3 5} \rightarrow \mathbf{3 7})$ redukcióját $\mathrm{NaBH}_{4}-$ trifluorecetsav rendszerben végeztük el. A 3-as helyzetbe reduktív alkilezéssel vezettünk be alkilcsoportot: aldehidekkel, aktívszén-hordozós palládiumkatalizátor jelenlétében hidrogén atmoszférában $(\mathbf{3 6} \rightarrow \mathbf{3 8})$. Ilyen módon a 2,4-dialkil-3,4-dihidroszármazékból (37) 2,3,4-trialkilszármazék (39) is elöállítható. A 3,4-dihidroszármazékoknál az ${ }^{1} \mathrm{H}$ és ${ }^{13} \mathrm{C}$ NMR spektrumokban jelkiszélesedést észleltünk a heterogyürü jelein $\left[C(4)-\mathrm{H}, C(4)-\mathrm{CH}_{3}, N(2)-\mathrm{CH}_{3}, N(3)-\mathrm{CH}_{3}\right]$. A jelek kiszélesedése, illetve egyes esetekben zajszint alá csökkenése a heterogyürü gátolt inverziójával volt magyarázható, mely jelenség különösen a sztérikusan zsúfoltabb származékoknál, jellemzően az $N(2)-, N(3)$ - és/vagy $C(8)$ helyettesített vegyületeknél jelentkezett.
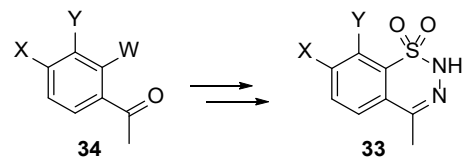

$$
\begin{aligned}
& X, Y=\mathrm{Cl}, \mathrm{OMe}, \mathrm{H} \\
& \mathrm{W}=\mathrm{H}_{\mathrm{B}} \mathrm{Br} \\
& \mathrm{R}^{1}=\text { alkil } \\
& \mathrm{R}^{2}=\mathrm{H}, \text { alkil }
\end{aligned}
$$
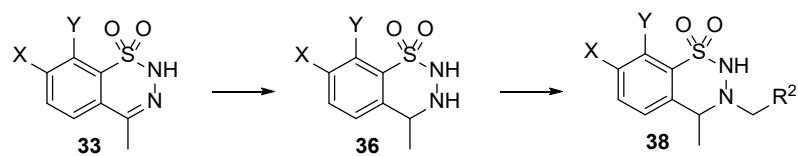

\begin{tabular}{l|l}
$N(2)$-alkilezés & $\mathrm{C}=\mathrm{N}$ redukció \\
bázis, alkil-hlg &
\end{tabular}

36

reduktiv alkilezés $\mathrm{Pd} / \mathrm{C} / \mathrm{H}_{2}, \mathrm{R}^{2} \mathrm{CHO}$
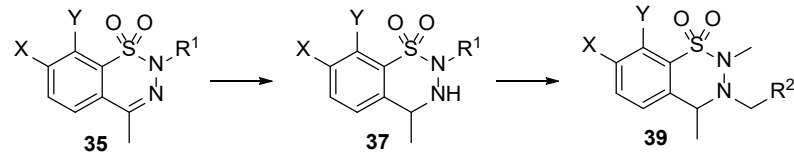

7. ábra. A 4-metil-BTD-ok acetofenonokból történő előállítása, alkilezése és redukciója.

\subsection{A 4-metil-BTD-ok reakciói aminokkal ${ }^{20}$}

Ezt követően a 7-es vagy a 8-as helyzetben klóratomot tartalmazó 2,4-dimetil-BTD-okat (40) aminokkal reagáltatva 7- vagy 8 -aminoszármazékokat (41) kaptunk (8. ábra). A 7,8-diklór-2,4-dimetil-BTD-ból $(\mathbf{4 0}, \mathrm{R}=\mathrm{Me}, \mathrm{Y}=\mathrm{Cl})$ regioizomerek keletkeztek: elektronikusan a 8 -as helyzet a preferált, de szekunder aminok esetében sztérikus okokból megnőtt a 7-szubsztitúció aránya. 1D selNOE és 2D NMR módszerekkel azonosítottuk a regioizomereket, valamint megfigyeltük, hogy a gyürüs aminoknál a 7-es helyzetben lehetőség van gyors gyürüinverzióra, ugyanakkor a 8-as helyzetben ez gátolt.

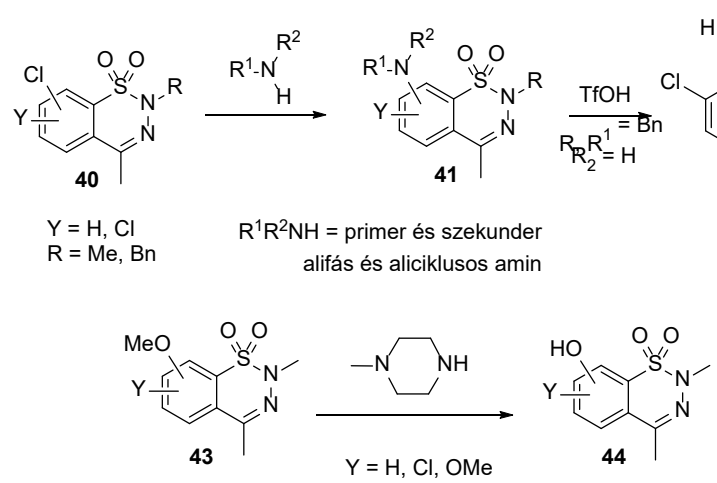

8. ábra. A klór-BTD-ok szubsztitúciója és a metoxivegyületek demetilezése aminokkal

Az N(2)-es helyzetben szubsztituálatlan vegyületek esetében nem müködött a klór-amin csere. Ezért kidolgoztunk egy védőcsoport stratégiát, mely során benzilcsoportot alkalmaztunk, amely tolerálta az aminálás reakciókörülményeit. A $41\left(\mathrm{R}=\mathrm{Bn}, \mathrm{Y}=7-\mathrm{Cl}, \mathrm{NR}^{1} \mathrm{R}^{2}=8-\mathrm{NHBn}\right)$ vegyület hasítását $100{ }^{\circ} \mathrm{C}$-on trifluormetánszulfonsavval végeztük el, így 42 vegyületet kapva (8. ábra). A 7-klór-8-metoxiszármazék aminálási reakciójában nem a várt szubsztitúció történt meg, hanem $O$-demetileződéssel a megfelelö fenol keletkezett. Ezt a módszert kiterjesztve, $N$-metilpiperazinnal megvalósítottuk különböző metoxi-BTD-ok (43) demetilezését, így hidroxi-BTD-okhoz (44) jutottunk (8. ábra).

\subsection{A BTD-ok átrendeződési reakciói ${ }^{21,22}$}

Felfedeztük, hogy a 3-acetil-7,8-diklór-2,4-dimetil-3,4dihidro-BTD-ot $(\mathbf{4 5}, \mathrm{R}=\mathrm{Me}) \mathrm{LiAlH}_{4}$-del reagáltatva az acetilcsoport várt redukciója helyett a megfelelö benzizotiazol-1,1-dioxiddá $(\mathbf{4 6}, \mathrm{R}=\mathrm{Me})$ alakul, diaza-[1,2]-Wittig típusú reakcióban (9. ábra). A továbbiakban a gyürüszükülést megfigyeltük más bázisok jelenlétében is, és $2 \mathrm{ekv}$ $\mathrm{NaOH}$-ot THF-ban alkalmazva kiváló termeléssel hajtottuk végre a 4-es helyzetben metil-, etil- vagy fenilcsoportot tartalmazó és a 4-H származékok (45) gyűrüszűkülését.
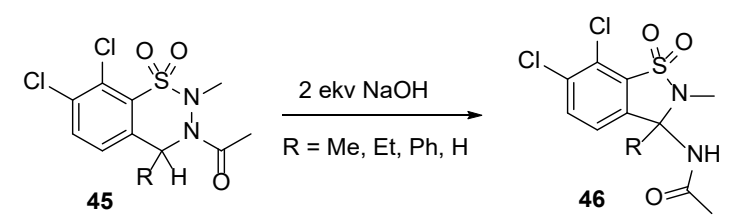

9. ábra. A 3-acetil-7,8-diklór-2-metil-3,4-dihidro-BTD-ok gyürüszükülése a megfelelő benzizotiazol-1,1-dioxidokká.

Megfigyeltük, hogy nagyobb mennyiségü bázis, 6 ekv $t$-BuOK alkalmazásával a 3-acetil-7,8-diklór-2,4-dimetil3,4-dihidro-BTD (45a) a megfelelő benzotiazin-1,1-dioxiddá (47a) alakul át, és a gyủrűszűkült termék (46a) csak kisebb mennyiségben keletkezik (10. ábra). 


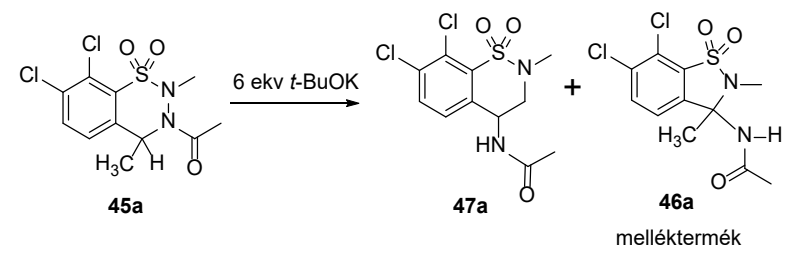

10. ábra. A 3-acetil-7,8-diklór-2,4-dimetil-3,4-dihidro-BTD átrendeződése a megfelelő benzotiazin-1,1-dioxiddá.
Kísérletesen megvizsgáltuk a reakciókörülmények hatását az átrendeződések termékszelektivitására, beleértve a bázis minőségét, mennyiségét és az alkalmazott oldószert. Azt találtuk, hogy erősen bázikus közeg szükséges a benzotiazin kialakulásához, egyéb esetben benzizotiazol keletkezik fötermékként. DFT számításokon alapulva igazoltuk, hogy monoanionos úton a benzizotiazol-1,1-dioxid keletkezése a preferált (11. ábra).

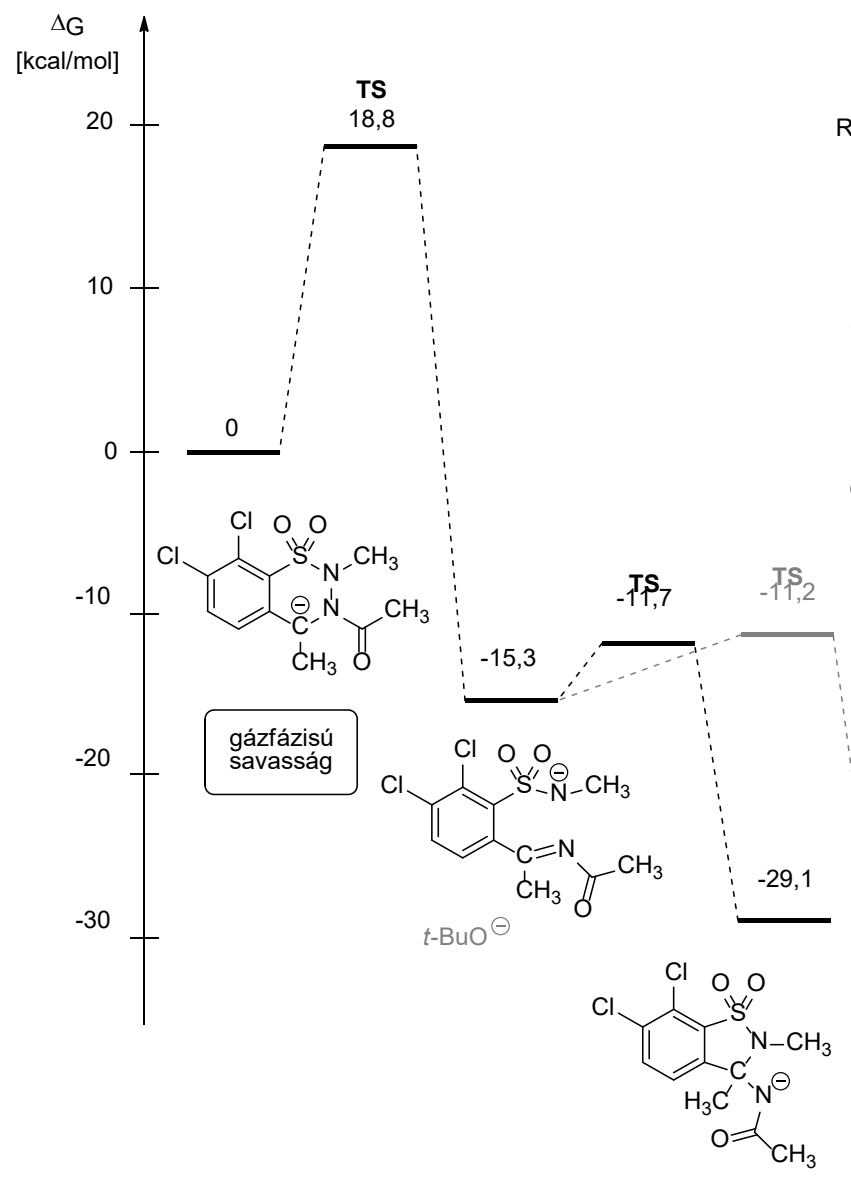<smiles>[R1]NS(=O)(=O)c1c(C(=C)NC(C)=O)ccc([R])c1[R]</smiles>

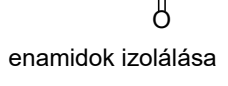

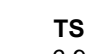

仓

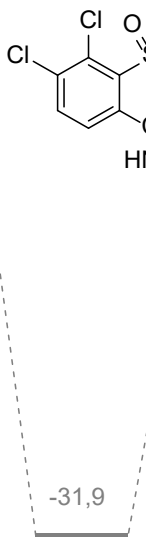

$-31,9$

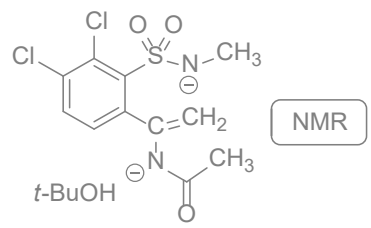

enamid dianion<smiles>[2H]N(C(C)=O)C1([2H])CN(C)S(=O)(=O)c2c1ccc(Cl)c2Cl</smiles>

deuterálás<smiles>CC(=O)NC1CN(C)S(=O)(=O)c2c1ccc(Cl)c2Cl</smiles>

$-19,5$

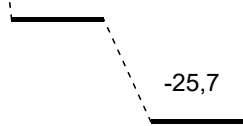

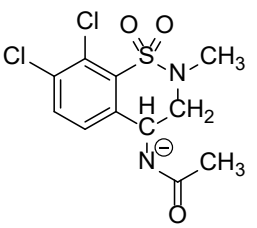

11. ábra. Reakciómechanizmus-számítások M06-2X/6-31+G* (smd: THF) szinten, és az intermedierek létezésének kísérletes bizonyítékai.

\section{diaza-[1,2]-Wittig}<smiles>[R]CNC1(N[R])c2ccc([R])c([R5])c2S(=O)(=O)N1[R]</smiles>

49

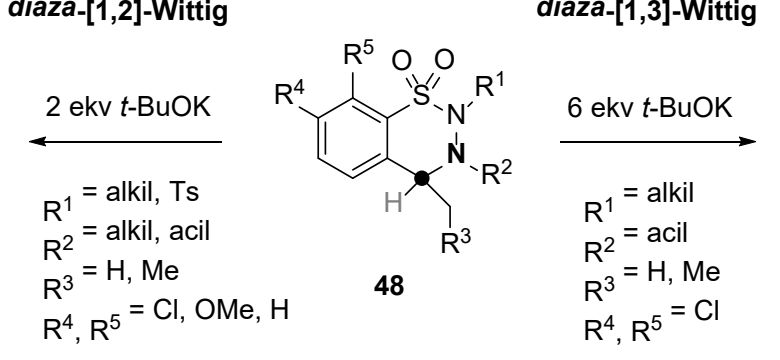

diaza-[1,3]-Wittig

12. ábra. A BTD-ok diaza-[1,2]- és diaza-[1,3]-Wittig-átrendeződési reakciói.

127. évfolyam, 2. szám, 2021. 
Ezt követően feltételeztük, hogy a benzotiazint eredményező reakcióút kulcsa egy enamid dianion intermedier (11. ábra) keletkezése lehet, amit NMR vizsgálatokkal megerősítettünk. Deuterálással sikerült egy karbanion intermediert is igazolni. Továbbá bebizonyítottuk, hogy $6 \mathrm{ekv}$ $t$-BuOK alkalmazásával a benziziotiazol gyürü felnyílik, és benzotiazinná alakítható.

Megvizsgáltuk a szubsztituensek hatását is az átrendeződési reakciókra (12. ábra). Ennek során 2 ekv $t$ BuOK-ot THFban alkalmazva kiterjesztettük a BTD-ok diaza-[1,2]-Wittig-átrendeződését $(\mathbf{4 8} \rightarrow \mathbf{4 9})$ a 2-es helyzetben alkil- vagy tozil-, a 3-as helyzetben alkil- vagy acilcsoportot, valamint az aromás gyürün a 7-es vagy 8-as helyzetben klóratomot vagy metoxicsoportot tartalmazó, illetve szubsztituálatlan származékokra. Bizonyos esetekben enamid köztiterméknél megállt a reakció (11. ábra), de a feldolgozás során savanyítással vagy a hőmérséklet emelésével kialakítható volt a benzizotiazol gyürü (12. ábra). Végül preparatív módszert dolgoztunk ki a 3-acil-2-alkil-7,8-diklór-4-metil-3,4-dihidro-BTD-ok benzotiazin származékokká (50) történő dia$z a$-[1,3]-Wittig-átrendeződésére, 6 ekv $t$ BuOK jelenlétében.

\section{4. Összefoglalás}

A doktori kutatómunka során kidolgozott eljárások változatosan szubsztituált benzotiadiazin-1,1-dioxidok és 3,4-dihidroszármazékaik szintézisét teszik lehetővé. Ezek önmagukban is gyógyszerszerű vegyületek, illetve az általunk kifejlesztett szintézismódszerek alkalmazásával széles körben tovább funkcionalizálhatóak az aromás gyürün, valamint a heterogyürü $N(2), N(3)$ és $C(4)$ atomjain, ezáltal további gyógyszerjelöltekké alakíthatóak. Tanulmányaink jelentősen hozzájárulnak a BTD vegyületek reaktivitásának és a diaza-Wittig-átrendeződések megismeréséhez.

\section{Köszönetnyilvánítás}

Gy. I. köszönetét fejezi ki az infrastrukturális és szakmai háttérért, amelyet a kísérleti munkához és az analízishez az Egis Gyógyszergyár Zrt., a számításos kémiához a BME Szervetlen és Analitikai Kémia Tanszék biztosított.

\section{Hivatkozások}

1. Wright, J. B.; Kalamazoo, M. US 3407197 US Pat. Appl.; Chem. Abstr. 1969, 70, 57914.

2. King, J. F.; Hawson, A.; Deaken, D. M.; Komery, J. Chem. Commun. 1969, 1, 33-34. https://doi.org/10.1039/c29690000033

3. Kacem, Y.; Hassine, B. B. Tetrahedron Lett. 2013, 54, 4023-4025. https://doi.org/10.1016/j.tetlet.2013.05.082

4. Lukács, G.; Porcs-Makkay, M.; Komáromi, A.; Simig, G. Arkivoc 2008, iii, 17-24. https://doi.org/10.3998/ark.5550190.0009.303

5. Lukács, G.; Porcs-Makkay, M.; Simig, G. Eur J. Org. Chem. 2004, 20, 4130-4140. https://doi.org/10.1002/ejoc.200400335
6. Nyulasi, B.; Németh, A.; Porcs-Makkay, M.; Kupai, J.; Lukács, G.; Simig, G.; Volk, B. Tetrahedron 2017, 73, 298-306. https://doi.org/10.1016/j.tet.2016.11.072

7. Lukács, G.; Porcs-Makkay, M.; Simig, G. Tetrahedron Lett. 2003, 44, 3211-3214. https://doi.org/10.1016/S0040-4039(03)00391-5

8. Porcs-Makkay, M.; Lukács, G.; Kapus, G.; Gacsályi, I.; Simig, G.; Lévay, G.; Mezei, T.; Végh, M.; Kertész, S.; Barkóczy, J.; Leveleki, C.; Hársing, L. G. WO 2008020255 PCT Intern. Pat. Appl.; Chem. Abstr. 2008, 148, 262627.

9. Porcs-Makkay, M.; Lukács, G.; Kapus, G.; Gacsályi, I.; Simig, G.; Lévay, G.; Mezei, T.; Végh, M.; Kertész, S.; Barkóczy, J.; Leveleki, C.; Hársing, L. WO 2008020256 PCT Intern. Pat. Appl.; Chem. Abstr. 2008, 148, 262626.

10. Porcs-Makkay, M.; Lukács, G.; Pandur, A.; Simig, G.; Volk, B. Tetrahedron 2014, 70, 286-293. https://doi.org/10.1016/j.tet.2013.11.058

11. Porcs-Makkay, M.; Kapiller-Dezsőfi, R.; Párkányi, L.; Pandur, A.; Simig, G.; Volk, B. Tetrahedron 2014, 70, 2169-2174. https://doi.org/10.1016/j.tet.2014.01.072

12. Porcs-Makkay, M.; Pandur, A.; Simig, G.; Volk, B. Tetrahedron 2015, 71, 44-50. https://doi.org/10.1016/j.tet.2014.11.046

13. Bach, R.; Harthong, S.; Lacour, J.: Nitrogen- and SulfurBased Stevens and Related Rearrangements, Chapter 3.20. Comprehensive Organic Synthesis $2^{\text {nd }}$ ed. (ed.: Knochel, P.; Molander, G. A.), Elsevier, 2014. ISBN: 978-0-08-097742-3 https://doi.org/10.1016/B978-0-08-097742-3.00326-8

14. Nakamura, A.; Kamiya, S. Chem. Pharm. Bull. 1974, 22, 2142-2146. https://doi.org/10.1248/cpb.22.2142

15. Wolfe, J. P.: The Wittig Rearrangement, Chapter 3.21. Comprehensive Organic Synthesis $2^{\text {nd }}$ ed. (ed.: Knochel, P.; Molander, G. A.), Elsevier, 2014. ISBN: 978-0-08-097742-3 https://doi.org/10.1016/B978-0-08-097742-3.00327-X

16. Gong, Y.; Bausch, M. J.; Wang, L. Heterocycles 2001, 55, $163-170$ https://doi.org/10.3987/COM-00-9087

17. Tayama, E.; Kobayashi, Y.; Toma, Y. Chem. Commun. 2016, 52, 10570-10573. https://doi.org/10.1039/C6CC04626F

18. Porcs-Makkay, M.; Gyüjtő, I.; Lukács, G.; Komáromi, A.; Tóth, G.; Garádi, Z.; Simig, G.; Volk, B. Chemistry Select 2019, 4, 8295-8300. https://doi.org/10.1002/slct.201901212

19. Gyüjtő, I.; Porcs-Makkay, M.; Lukács, G.; Pusztai, G.; Garádi, Z.; Tóth, G.; Nyulasi, B.; Simig, G.; Volk, B. Synth. Commun. 2019, 49, 3475-3485. https://doi.org/10.1080/00397911.2019.1673777

20. Gyüjtő, I.; Porcs-Makkay, M.; Várda, E. F.; Pusztai, G.; Tóth, G.; Simig, G.; Volk, B. Synth. Commun. 2020, 50, 34133423. https://doi.org/10.1080/00397911.2020.1801748

21. Porcs-Makkay, M.; Gyüjtő, I.; Simig, G.; Volk, B.: Tetrahedron 2016, 72, 8463-8469. https://doi.org/10.1016/j.tet.2016.11.021

22. Gyüjtő, I.; Porcs-Makkay, M.; Szabó., G.; Kelemen, Z.; Pusztai, G.; Tóth, G.; Dancsó, A.; Halász, J.; Simig, G.; Volk, B.; Nyulászi, L. J. Org. Chem. 2021, 86, 1685-1700. https://doi.org/10.1021/acs.joc.0c02512 


\section{Synthesis and rearrangements of 1,2,3-benzothiadiazine-1,1-dioxide derivatives}

Around 20 years ago, research was initiated at Egis Plc. aiming at the development of $2 H$-1,2,3-benzothiadiazine-1,1-dioxides (BTDs) potentially exhibiting CNS activity. This heterocycle is structurally related to phthalazinone and 1,2,4-benzothiadiazine-1,1-dioxide drug scaffolds. In addition, BTD can serve as a core structural unit to which pharmacophores can be attached. Although interesting chemical aspects were discovered in the course of the synthesis of these compounds, there was no opportunity for their detailed investigation. Therefore, the aim of my $\mathrm{PhD}$ research was to widen the scope of the prepared BTDs, to present improved synthetic routes, and to study the surprising discoveries emerging during the research.

A lithiation-based methodology was elaborated starting from aceto- and benzophenones and benzaldehydes by the researchers of Egis in order to afford variously substituted BTDs. The carbonyl group was protected with ethylene glycol to give the corresponding 1,3-dioxolanes. The synthesis of sulfonyl chlorides was elaborated via lithiation of ketals with BuLi followed by consecutive treatment of the obtained aryllithium species with sulfur dioxide and sulfuryl chloride. This strategy was demonstrated on variously substituted benzophenone ketals. As far as acetophenone ketals are concerned, mainly carbon dioxide was employed as the electrophile to map the regioselectivity, and only a few examples were published using sulfur dioxide. In case of 4-unsubstituted (4-H) BTDs, for the ring closure of the 2-chlorosulfonyl acetals obtained in similar manner, two methods were elaborated: using either hydrazine or acethydrazide, and the protective group removal was conducted under acidic conditions. Alkylation of 4-H BTDs led to the formation of both $N(2)$-alkyl and mesoionic $N(3)$-alkylated products. The $\mathrm{C}=\mathrm{N}$ double bond was reduced with $\mathrm{NaBH}_{4} / \mathrm{TFA}$ or $\mathrm{PtO}_{2} / \mathrm{H}_{2}$ systems. Reductive alkylation was performed with paraformaldehyde to introduce a methyl group into position 3 .

During our research, 4-aryl-BTDs were obtained via the ring closure of the corresponding chlorosulfonyl ketals using hydrazine or acethydrazide. 3,4-Dihydro and/or 2-alkyl derivatives seemed promising based on pharmacological tests. Therefore, the $\mathrm{C}=\mathrm{N}$ double bond was hydrogenated in the presence of $\mathrm{PtO}_{2}$. 2-Alkylation reactions were conducted using $\mathrm{NaH}$ or $t$-BuOK bases and alkyl iodides to introduce 2-methyl, -ethyl and -butyl groups. It occurred with good regioselectivity compared to the 4-H BTDs, when the $N(2)$ - and $N(3)$-alkylated products were formed in roughly the same amount. $N(2)$-Alkylation with 1-bromo-4-chlorobutane allowed the introduction of a pharmacophore by nucleophilic replacement of the terminal leaving group.

A process was elaborated for the preparation of 4-methyl-BTDs starting form acetophenones. The carbonyl group was protected as a dioxolane with ethylene glycol under MW conditions or in the presence of triethyl orthoformate. Sulfonyl chlorides were prepared by trapping the corresponding aryllithiums with sulfur dioxide, followed by treatment of the isolated aryl sulfinate with sulfuryl chloride. In case of the unsubstituted and the para-methoxy substituted acetophenone, the ortho-bromo derivatives were used as the starting materials. The protecting group was removed under acidic conditions and the ring closure was conducted with hydrazine or acethydrazide. $N(2)$-Alkylation was conducted with methyl, ethyl and benzyl halogenides. The reduction of $N(2)$-unsubstituted or alkylated compounds were performed with $\mathrm{NaBH}_{4} /$ TFA instead of catalytic hydrogenation in the presence of $\mathrm{PtO}_{2}$. Alkyl groups were introduced to position 3 via reductive alkylation with aldehydes in the presence of palladium on charcoal under hydrogen atmosphere. Based on the elaborated process, 2,4-dimethyl-3,4-dihydro compounds could be transformed to the 3,4-saturated 2,3,4-trimethyl derivatives.
Furthermore, 7- or 8-chloro substituted 2,4-dimethyl-BTDs were reacted with amines to give the corresponding 7- or 8-amino compounds. Reaction of 7,8-dichloro-2,4-dimethyl-BTD afforded a mixture of regioisomers in most cases: secondary amines could be mainly introduced to the sterically less crowded position 7, whereas primary amines were more likely to attack at the electronically more favored position 8 . We also aimed at the synthesis of 2-unsubstituted BTDs bearing an amino group at the aromatic ring. Benzyl group was employed as a protecting group to withstand the harsh conditions of the chlorine-amine exchange reaction. The debenzylation was performed with trifluoromethanesulfonic acid at $100{ }^{\circ} \mathrm{C}$. In the reaction of 8chloro2,4dimethyl-7-methoxy-BTD with amines, $O$-demethylation occurred leading to the corresponding phenol, instead of substitution of the chlorine atom. The $O$-demethylation was also demonstrated on other methoxy-BTDs using $N$-methylpiperazine.

Attempted reduction of the acetyl moiety of 3-acetyl-7,8-dichloro2,4-dimethyl-3,4-dihydro-BTD with $\mathrm{LiAlH}_{4}$ led surprisingly to the corresponding 2,3-dihydro-1,2-benzisothiazole 1,1-dioxide, a ring-contracted product. Thus, $\mathrm{LiAlH}_{4}$ did not act as a reducing agent but as a base in the reaction. This base-mediated rearrangement was then extended to other substituents $(\mathrm{H}, \mathrm{Et}, \mathrm{Ph})$ in position 4 using 2 eq solid $\mathrm{NaOH}$ in THF with high yields. Treatment of 3-acetyl-7,8-dichloro-2,4-dimethyl-3,4-dihydro-BTD with 6 eq $t$-BuOK in THF gave rise to the formation of the corresponding 1,2-benzothiazine 1,1-dioxide as the major product besides the 1,2-benzisothiazole 1,1-dioxide. The effect of reaction conditions (including e.g. solvent, base and the amount thereof) were investigated on the product selectivity of the two ring transformations. We found that strongly basic conditions were necessary for the formation of benzothiazine, otherwise benzisothiazole would be the sole product. The mechanism of a monoanionic pathway was calculated which fully justified the formation of benzisothiazole on thermodynamic as well as on kinetic grounds. The key intermediate of the proposed route toward benzothiazine was an enamide dianion, which was supported by NMR studies. The presence of a benzothiazine carbanion intermediate was proved by trapping with $\mathrm{D}_{2} \mathrm{O}$, as well. The reversibility of the rearrangements was investigated, and revealed that the treatment of benzisothiazole with 6 eq $t$-BuOK induced a ring opening resulting in the benzothiazine. After that, we intended to widen the substrate scope. The substituent effect on the outcome of the rearrangements was evaluated experimentally. Using 2 eq $t \mathrm{BuOK}$ in THF, the diaza-[1,2]-Wittig rearrangement was extended to substrates bearing alkyl or tosyl groups at position 2, alkyl or acyl groups at position 3, and various substituents at the aromatic ring. Modifications in the aromatic substitution pattern (in respect to the 7,8-dichloro derivative) resulted in enamides as the main products in the rearrangement reaction. Cyclization could be fostered by quenching with $1 \% \mathrm{HCl}$ or by heating. A targeted preparative process was elaborated for diaza-[1,3]-Wittig rearrangement of 3-acyl-2,4-dialkyl-7,8-dichloro-3,4-dihydro-BTDs.

In conclusion, processes were elaborated for the preparation of variously substituted benzothiadiazine-1,1-dioxides and their 3,4-dihydro congeners. The synthesized compounds are drug-like themselves, moreover they can be further functionalized at the aromatic ring and at positions $N(2)$ and $N(3)$ to transform them to other drug candidates. Our studies significantly contributed to the exploration of the chemistry of benzothiadiazine-1,1-dioxides and to that of diaza-Wittig rearrangements. 